
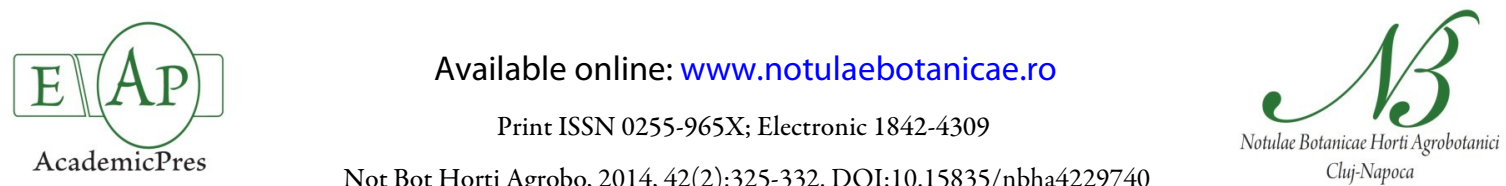

\title{
Increase of Biofuel Crop Production in Romania over the Last Decades - Possible Impacts on Environment, Greenhouse Gas Emissions and Land Use
}

\author{
Vasilica STAN ${ }^{1 *}$, Gina FÎNTINNERU², Viorel ION ${ }^{1}$ \\ ${ }^{1}$ University of Agronomic Sciences and Veterinary Medicine, Plant Sciences Department, \\ 59 Mărăşti, Sector 1, 011464, Bucharest, Romania; vstan@agro-bucuresti.ro (*corresponding author) \\ ${ }^{2}$ University of Agronomic Sciences and Veterinary Medicine, Economy, Accounting and Rural Tourism Department, \\ 59 Mărăști, Sector 1, 011464, Bucharest, Romania
}

\begin{abstract}
The interest in biofuels is growing globally and the demand for bioenergy throughout the European Union will expand considerably in the following years. Numerous studies have shown that energy resulted from green plants has much to offer, as it is renewable and largely carbon-neutral compared with fossil fuel combustion. However, this is an increasingly controversial issue due to its strong impact on economy, environment and land use. Romania is one of the European Union Member States with a large biofuel production resources, owing to its high land agricultural area and good conditions for cereal and oilseed growth. There has been an increasing tendency to grow biofuels in the Romanian cultivated areas over the last decades; however, it is difficult to know if biofuel production is sustainable in this part of Europe and what impact may have unsustainable production since there is no or scientific research on this topic. The aim of this paper is to present the dynamics of biofuel crops (biodiesel) areas in Romania over the last decade, and to introduce a short review on the possible impacts on the environment, greenhouse gas emissions (GES) and land use in order to defend the need of information for our particular situation.
\end{abstract}

Keywords: oilseed crops, rapeseed, sunflower, sustainable biofuels, sensitive regions

\section{Introduction}

It is difficult to predict how much bioenergy will be used in the future, particularly because the bioenergy policies have changed rapidly lately, often due to climate policies, high oil price or security of supply considerations (Kampman et al., 2008). However, the demand for bioenergy will expand considerably in Europe in the following years. The 2009 European Union (EU) Directive on Renewable Energy (RED) requires that $20 \%$ of all the energy consumed in the EU and $10 \%$ of all transport fuel should be renewable by 2020 (Directive 2009/28/EC). It is known that transport is one of the main contributors to GHG emissions in many countries around the world (IEA, 2013). The Directive does not prescribe how much of this renewable energy should be bio-based but the $10 \%$ target for transport means either electric vehicles (to the extent that electricity is generated from renewable sources) or biofuels (Kuhlman et al., 2013).

The general trend is for biofuels production to become more prevalent (EC, 2013) and numerous studies show that energy generated from green plants has much to offer, as it is renewable and largely carbon neutral in comparison to fossil fuel combustion (Rowe et al., 2009; Ravindranath et al., 2011). Nevertheless, several others studies sustain that biofuels are an increasingly controversial issue (Negash and
Sweinnen, 2013) due to their strong impact on economy, the environment and land use (Scarlat et al., 2008; Rowe et al., 2009; Raghu et al., 2011; Ravindranath et al., 2011; Secchi et al., 2011; Erb et al., 2012; Thompson and Meyer, 2013). Consequently, it is of great importance to find ethically, economically and environmentally viable biofuels in the near future (Pakarinen et al., 2011; Gamborg et al., 2012).

The potential of using crops for biofuel production is an important consideration in investment strategies (EC, 2013). Thus, many farmers and investors in agriculture have become increasingly interested in biofuel crops. The most important reason is related to the EU policy which promotes biofuels through mandatory targets, as already shown. In practical terms, the main source will be biofuels which lack sufficient domestic sources to fulfil the EU target (Levidow, 2013). The mandatory share of biofuels in the total fuel consumption (10\%) out of the transport sector of for all Member State (10\%) by 2020 is likely to have a strong impact on the cereals, oilseeds and sugar beet demand for biofuel production (Scarlat et al., 2008).

Many questions arise when we talk about the growth of interest in biofuels production, mainly concerning the especially dedicated policies which may result in important changes in various fields of society, particularly economy. 
In Romania mass-media caught our attention after reporting on the increase of foreign investors' interest in the Romanian arable land (Mediafax, 2010; Ziarul Financiar (ZF), 2010; ZF, 2012), especially in its use for biofuel crops production. Also, a scientific article titled Bioenergy and Land Use: Framing the Ethical Debate reported on "the current policy context on bioenergy within the EU", and made a critically analysis on the ethical framing of the debate after BBC News had released a story according to which "Biofuels targets are «unethical»" (Gamborg et al., 2012). As already shown, energy markets are a significant driver in the overall trend of large-scale land acquisition. A clear link can be established between the EU bioenergy policy and the strong interest of European companies in acquiring agricultural land (EC, 2013). The biofuel sector is characterized by a wide range of stakeholders with diverse interests, and in agricultural markets biofuel processors compete directly with food processors and animal-feeding operations for commodities. From the viewpoint of an individual farmer, it is not important what end use a prospective buyer has in mind for the crop. Farmers will sell to an ethanol or biodiesel processor if the price they receive is higher than they could obtain from a food processor or a feeding operation. If the price of biofuels is high enough, it will bid agricultural commodities away from other uses (FAO, 2008). Moreover, an individual farmer will produce feedstock for biofuels if the net revenue $s /$ he earns is greater than that received for alternative crops or uses. The decision-making process for a biofuel crop is the same as for any other crop. Farmers choose what to produce on the basis of expected net revenues and perceptions of risk, and may use formal models, experience, tradition or a combination of the three in making their choice (FAO, 2008).

Looking at Romanian agriculture, we wonder not only about how much the biofuels cultivated areas are grown but also how sustainable biofuel production is in Romania and what impact unsustainable production may have. As reported by Mosnier et al. (2013), biofuel production may probably lead to an overall intensification of agricultural production, changes in regional mixes, and production reallocation to other areas. The environmental effects of these changes are heterogeneous but often negative. Most existing studies do not adequately address the feedback effect of biofuels on agricultural intensity. Moreover, there is a highly extensive debate on the possible consequences of energy crops production, mostly related to food security. As more land is devoted to biofuel production, there will be less land available for growing traditional crops for food production purposes (Thompson and Meyer, 2013).

Romania is one of the European Union Member States with a large potential to produce biofuels owing to its high land agricultural areas and better conditions for cereals and oilseeds (Scarlat et al., 2008). Nevertheless, its potential cannot be maintained without sustainable technologies and good agricultural practices. There is still no research in Romania about the possible impact of the biofuel crop production upon the environment, greenhouse gas emissions and land use.

The purpose of this paper is not to criticize the increase biofuel crop areas or to analyse how ethical is to produce biofuels, but to forward general analysis of the current situation in Romania and to draw attention to the need to assess the potential impact. Thus, the aim of this paper is: (1) to present the dynamics of the biofuel crops (biodiesel) areas in Romania over the last decade, and to reveal the growth rate of bio-diesel production after Romania joined the EU in 2007; (2) to do a short review about the possible impact upon the environment, greenhouse gas emissions and land use, as they already reported by numerous authors, especially from the developed countries, in order to sustain future research under the Romanian conditions. Romania has ratified the Convention on Climate Change engaging in reducing emissions of greenhouse gases and, in order to fulfill commitments, Romania needs good knowledge of the situation which cannot be achieved otherwise but through scientific research under real circumstances (soil, climate, agricultural technologies and practices, etc.). Moreover, the most important areas cultivated with biofuel crops are located in sensitive regions (e.g. the Great Island of Braila) with an impact on soil, groundwater, surface water (especially Danube) and biodiversity. In addition, social impact needs to be considered.

The official data from the National Institute of Statistics (NIS) and EUROSTAT was used for an overview of the dynamics of the biofuel crops (biodiesel) areas in Romania, and for the growth rate of bio-diesel production after it joined the EU in 2007. For the short review, we did literature research based on international scientific databases (e.g. www.sciencedirect.com), EU and FAO reports, etc.

\section{Biofuel crops}

Globally, there are numerous supply biomass sources for energy purposes, distributed across large and diverse geographical areas (Tab. 1). The large growing area has lately been in the field of liquid biofuel production for transport using agricultural crops as feedstocks (FAO, 2008). The main liquid biofuels are ethanol and biodiesel, and most of them are produced from conventional food and feed crops (Scarlat et al., 2008; Ewing and Msangi, 2009; Spiertz and Ewert, 2009; Rathmann et al., 2010; Ravindranath et al., 2011).

In Romania, growing oilseed plants (sunflower, soybean, rapeseed, flax, castor, etc.) on large areas has become usual after the Second World War. Out of these plants, sunflower was introduced by the middle of the $19^{\text {th }}$ century, as the main plant cultivated for oilseed production (Hera et al.,

Tab. 1. Crops used as feedstock for ethanol and biodiesel production (FAO, 2008)

\begin{tabular}{ll}
\hline \multicolumn{1}{c}{ Ethanol } & \multicolumn{1}{c}{ Biodiesel } \\
\hline $\begin{array}{l}\text { Sugar crops: sugar cane, sugar } \\
\text { beet, sweet sorghum }\end{array}$ & $\begin{array}{l}\text { Oil crops: rapeseed, palm oil, } \\
\text { soybean, sunflower, peanut, } \\
\text { jatropha }\end{array}$ \\
$\begin{array}{l}\text { Starchy crops: maize, wheat, } \\
\text { barley, rye, potatoes, cassava }\end{array}$ & \\
$\begin{array}{l}\text { Cellulosic crops: switchgrass, } \\
\text { miscanthus, willow, poplar, } \\
\text { crop stover }\end{array}$ \\
\hline
\end{tabular}


327

1989) although on a very limited area, and sunflower oil was used only for feeding purposes. In 1910, sunflower was cultivated only on 672 ha; however, in 1938 the surface increased to 200,000 ha. After the Second World War (1945), the sunflower-grown area was 496.5 thousands ha, and reached 526.7 thousands ha by 1971-1975.

Soybean is one other important plant cultivated in Romania both for oil and as protein source for animal feeding. Only 7000 ha were cultivated with soybean between 1948 and 1960; by the beginning of 1980, the area cultivated with soybean increased to 325 thousands ha (Munteanu et al., 1995).

Rapeseed, now the dominant oilseed crop for biodiesel production in Europe (Ravindranath et al., 2011), was cultivated for the first time in Romania at the beginning of twentieth century (1913 - 80,000 ha). In 1938, the rapeseed cultivated area decreased to 41.5 thousands ha. Between 1940 and 1960, the rapeseed-grown area still remained small due to the increase in sunflower, flax and castor grown areas but also due to rapeseed sensitivity to winter and later hoar-frost during flowering (Bîlteanu et al., 1983). However, the changes in the Romanian economy after 1990 have led to the increase in rapeseed-grown areas in Romania over the last two decades.

However, there has been an increasing tendecy to extend the biofuel crop grown areas in Romania over the past decades. This policy has been further motivated by the desire to reduce dependency on fossil fuel imports and to stimulate rural development and the agricultural sector (Banse et al., 2011).

\section{Past and present trend of biofuel crop growth in \\ Romania}

In this part of the article, we attempt to explore the effects of the currently implemented policies in Romania by observing the changes in the agricultural production structure between 1990 and 2013. We aim at identifying the existence of any productions that have been discarded or scaled down so as to provide land for bio-energy crop production.

During the analysed period, while reducing arable land by $13.3 \%$, a more or less proportional decrease in the surface occurred for the main crops (for some, such as protein crops, industrial ones, medicinal and aromatic plants, etc., the area was dramatically reduced). Oilseed crops, however, recorded an

Tab. 2. Structure of main crop grown areas (\%) in Romania, 1990-2013

\begin{tabular}{ccccccc}
\hline Crops (\%) & 1990 & 1995 & 2000 & 2005 & 2010 & $2013^{*}$ \\
\hline Cereals & 60.67 & 69.87 & 66.53 & 69.27 & 64.56 & 66.38 \\
Pulses & 1.38 & 0.68 & 0.49 & 0.52 & 0.48 & 0.54 \\
$\begin{array}{c}\text { Oilseed } \\
\text { crops }\end{array}$ & 6.96 & 8.75 & 12.56 & 14.24 & 18.06 & 17.47 \\
$\begin{array}{c}\text { Herbs and } \\
\text { aromatics } \\
\text { Potatoes, }\end{array}$ & 0.29 & 0.22 & 0.05 & 0.05 & 0.20 & 0.06 \\
$\begin{array}{c}\text { vegetables, } \\
\text { melons }\end{array}$ & 5.73 & 5.46 & 6.62 & n.a & n.a & n.a \\
$\begin{array}{c}\text { Total } \\
\text { Tource: own calculation }\end{array}$ & 100 & 100 & 100 & 100 & 100 & 100 \\
\hline $\begin{array}{c}\text { Son National Institute of Statistics } \\
\text { ("preliminary data) data, }\end{array}$ & & & & &
\end{tabular}

increase by $118 \%$ in the cultivated area, thus reaching a share that was 2.5 times higher in crop structure in 2013, as compared to 1990 (Tab.2).

The growth rate of the oilseed crops grown areas was regionally differentiated. The largest grown areas were SouthEast and South Muntenia, Romania's major agricultural basins (Fig. 1). Together they covered about $63 \%$ of the cultivated area both in 1995 and 2013, with a growth rate close to the national average rate. Higher growth rates were recorded in the areas grown with oilseed crops in the Central and NorthEastern regions (Tab. 3).

The changes within the category of oilseeds crops over that period are also interesting. The two crops, sunflower and rapeseed, dominated the area in 2013, together accounting for $95 \%$ of the total area cultivated with oilseed plants. The most spectacular growth was recorded in rapeseed, the major crop for biodiesel in Europe: its surface increased 21 times between 1990 and 2013, with a peak in 2010, when it reached 38\% of the oilseed crops (Fig. 2).

Oilseed yield recorded an increasing tendency over the period 1990-2013 (Fig. 3). Rapeseed was notable (a threefold yield increase), as well as the soybean. Yield levels were still below those recorded in the EU 15 .

The yield level was likely to depend on the nature of the production systems. Rapeseed was the crop with the lowest share in the small individual farms, tending to be predominant in larger agricultural societies and companies (Tab. 4), which, we assume, used more intensive agricultural practices as compared to individual farms. However, one of the positive implications of biofuel production, such as the creation of rural jobs, seemed not to be fully understood, as individual farms chose to cultivate it in a smaller proportion compared with other crops. In the case of the biofuel production developed using mechanization, instead of more labour-intensive production techniques that replaced traditional agriculture, it could lead to the loss of employment. It remains to be investigated in the future whether these benefits (jobs creation and rural development) occur in other stages of the Romanian supply-chain (transportation, processing and marketing), as well as the type of relationship established between producers (suppliers) and processing companies.

Tab. 3. Dynamics of oilseed crop areas (ha) in the main development regions in Romania (1990-2013)

\begin{tabular}{|c|c|c|c|c|c|}
\hline \multirow{2}{*}{ Region } & \multicolumn{4}{|c|}{ Oilseed - crop areas (ha) } & \multirow{2}{*}{$\begin{array}{c}2013 / \\
1990(\%)\end{array}$} \\
\hline & 1990 & 2000 & 2007 & $2013^{*}$ & \\
\hline $\begin{array}{l}\text { North- } \\
\text { West }\end{array}$ & 19556 & 49288 & 72244 & 59045 & 2.02 \\
\hline Central & 2289 & 3562 & 8933 & 15895 & 5.94 \\
\hline $\begin{array}{l}\text { North- } \\
\text { East }\end{array}$ & 42104 & 85481 & 167954 & 168598 & 3.00 \\
\hline South-East & 197397 & 377633 & 443161 & 471009 & 1.39 \\
\hline $\begin{array}{l}\text { South- } \\
\text { Muntenia }\end{array}$ & 211110 & 346296 & 445948 & 437782 & 1.07 \\
\hline $\begin{array}{l}\text { Bucharest- } \\
\text { Ilfov }\end{array}$ & 6600 & 13428 & 12224 & 13768 & 1.09 \\
\hline $\begin{array}{c}\text { South- } \\
\text { West } \\
\text { Oltenia }\end{array}$ & 87295 & 119388 & 96204 & 148133 & 0.70 \\
\hline Total & 654723 & 1067421 & 1340374 & 1426874 & 1.18 \\
\hline
\end{tabular}




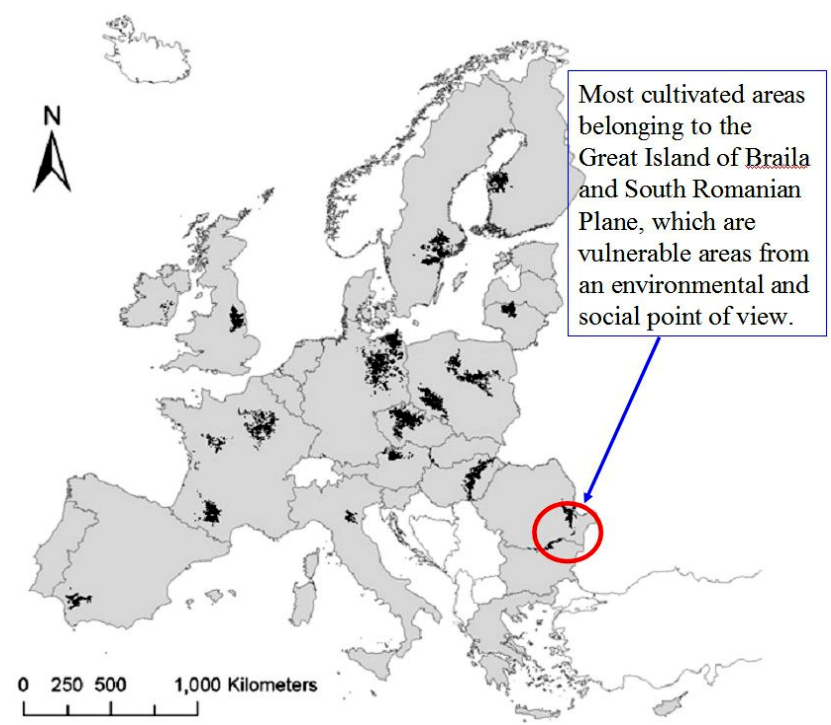

Fig. 1. Potential hotspots of biofuel crops in 2010: i.e. locations where biofuel crops are allocated by the Eururalis biofuels model (Banse et al., 2011)

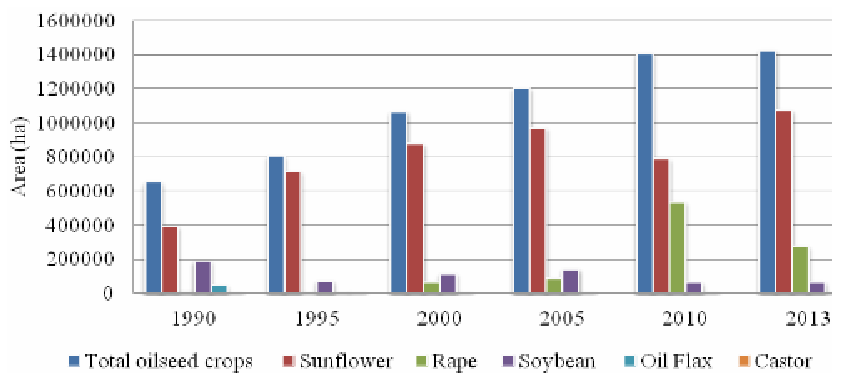

Fig. 2. Oil crop areas (ha) dynamics in Romania, 1990-2013 (Source: NIS)

The joint effect of both yield and cultivated areas increase generated a specific trade evolution, especially after Romania joined the EU in 2007. The intra and extra community export of oilseeds increased about 25 times (Fig. 4). Throughout the analysed period exports were predominantly oriented towards the intra-Community market. However, we cannot say the same about imports which, at the beginning of the analyzed interval, were predominantly based on extra EU markets. Dependence on intra-community imports increased after 2007 and reached $83 \%$ in 2010 (Fig. 5).

With all the changes in crop structure, Romania stands at European level by the growth rate of bio-diesel primary production recorded over the last years.

If 10 years ago only six EU countries contributed to the achievement of bio-diesel production (Tab. 5), in 2012 all MS, except Estonia and Luxembourg, were active in this area. The EU's primary production of bio-diesel increased almost eight times over the last decade.
While $60 \%$ of the production was covered by the Member States with long tradition in this field in 2012, significant growth rates were noticed in the new player countries. Romania recorded the second biggest growth rate at the EU level.

\section{Biofuel crops production and possible impacts: A short review}

The recent global economic crisis and the simultaneous crash in agricultural commodity prices have brought critical attention to the potential conflicts between biofuel production, land use and food security (Hought et al., 2012). The enhanced demand in biofuel crops under the EU biofuel directive has a strong impact on agriculture at the global and European level (Banse et al., 2011).

In the developed countries, both the scientific and policy dimensions of sustainable bioenergy development are evolving rapidly (almost on a weekly basis). A comprehensive understanding of the relevant issues, including land-use change, and proper assessment of greenhouse gas balances are essential in order to ensure that bioenergy crops have a positive and sustainable impact on climate-protection efforts (FAO, 2008).

At the international level, numerous studies are dedicated to environmental impacts, land use changes, and greenhouse gases emissions of biofuel crops production (Scarlat et al., 2008; Iriarte et al., 2010; Rathmann et al., 2010; Iriarte et al., 2011; Lechon et al., 2011; Popp et al., 2011; Secchi et al., 2011; Piroli et al. 2012; Lewidow, 2013). Their impact may vary with region or country, biofuel crop, production scale, land category, cultivation practices (irrigation), fertilizer application and conversion technologies (Scarlat et al., 2008; Iriarte et al., 2010; Ravindranath et al., 2011).

\section{Biofuel crops production and the environment}

The policy-driven expansion of biofuel is a highly controversial and wholly-debated topic in terms of environmental benefits and impacts (Baffes, 2013). The multiple and diverse environmental impacts of bioenergy development do not substantially differ from other forms of agriculture (FAO, 2008). They are related to the type and rate of fertilizers, tillage systems, use of pesticides, etc.

Different feedstocks vary in terms of soil impacts, nutrient demand and the extent of land preparation they require. Both land-use change and intensification of agricultural production on existing croplands can have significant adverse impacts on soils; however, this impact just as for any crop - depends critically on the farming techniques. Inappropriate cultivation practices can reduce soil organic matter and increase soil erosion by removing

Tab. 4. Weight of the main oilseed crops in the individual farms production structure in Romania, 2005-2013

\begin{tabular}{ccccccc}
\hline \multirow{2}{*}{ Crops } & \multicolumn{2}{c}{2005} & \multicolumn{2}{c}{2010} & \multicolumn{2}{c}{$2013^{*}$} \\
\cline { 2 - 7 } & Total (ha) & $\begin{array}{c}\text { f.w. Small individual } \\
\text { farms (\%) }\end{array}$ & Total (ha) & $\begin{array}{c}\text { f.w. Small individual } \\
\text { farms (\%) }\end{array}$ & Total (ha) & $\begin{array}{c}\text { f.w. Small individual } \\
\text { farms (\%) }\end{array}$ \\
\hline Oilseeds crops & 1205523 & 35.6 & 1409706 & 33.0 & 1426874 & 37.8 \\
Sunflower & 970950 & 41.1 & 790814 & 46.2 & 1074583 & 43.14 \\
Rapeseed & 87783 & 15.3 & 537330 & 15.5 & 276596 & 16.6 \\
Soybean & 143085 & 11.1 & 63948 & 22.8 & 67672 & 42.5 \\
\hline
\end{tabular}

Source: own calculations on NIS data ${ }^{*}:$ preliminary data) 


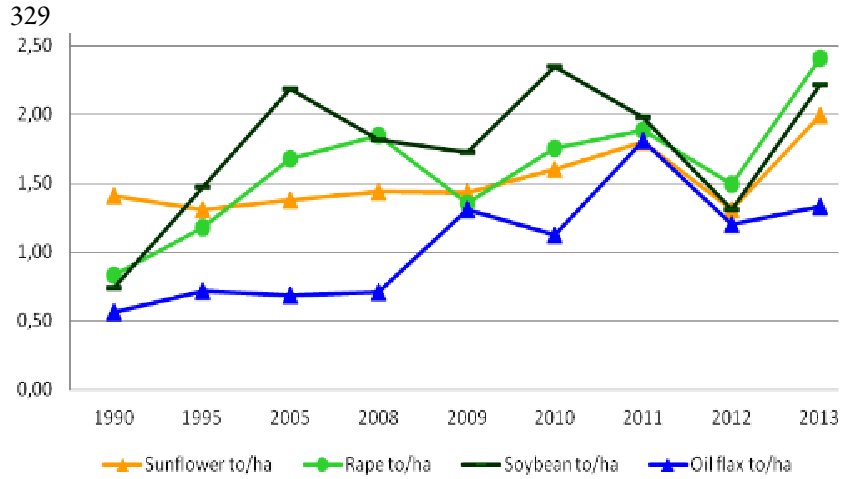

Fig. 3. Evolution of the average production (tons/ha) for main oil crops in the period 1990-2013

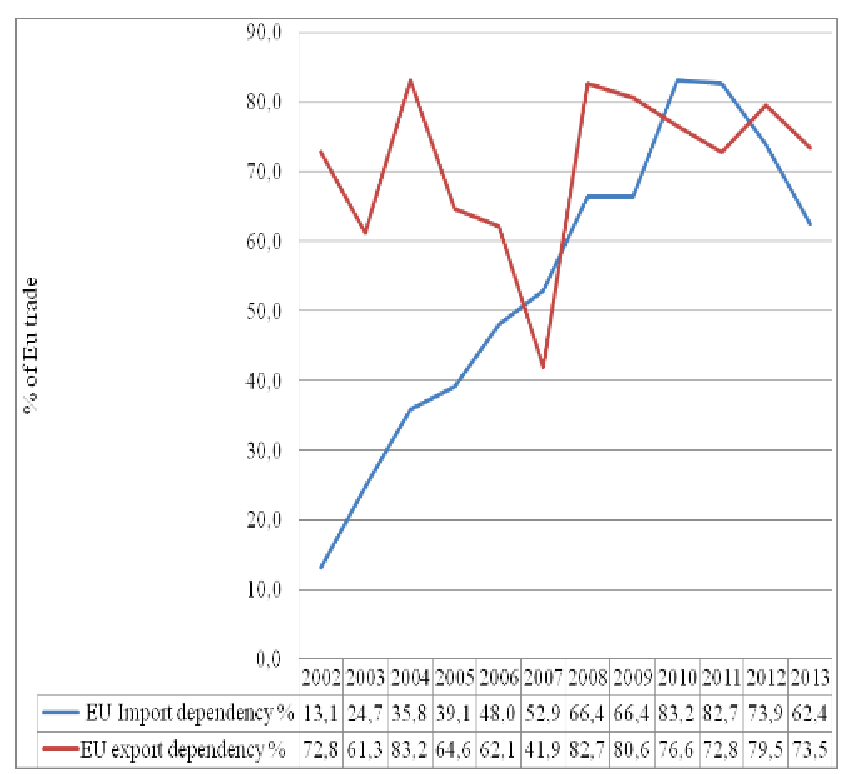

Fig. 5. Intra-community dependence on oilseeds trade, 20022013 (Source: MADR, 2013)

permanent soil cover. The removal of plant residues can reduce soil nutrient contents and increase greenhouse gas emissions through losses of soil carbon (FAO, 2008).

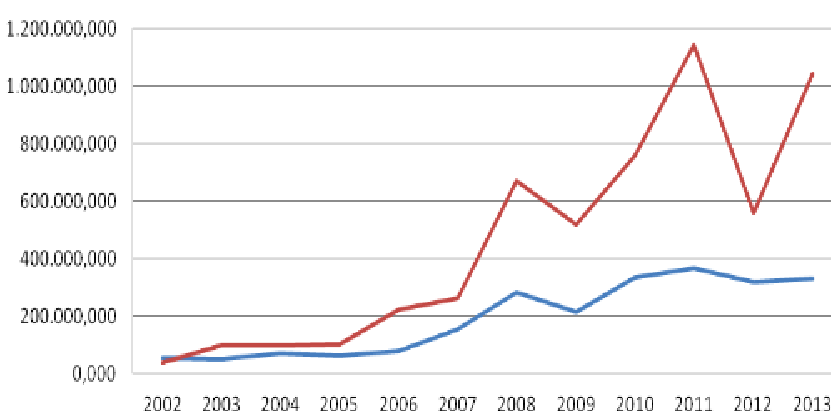

$$
\text { -Import -Export }
$$

Fig. 4. Oilseeds international trade (intra and extraCommunity) of Romania, 2002-2013, \$ (source: Romanian Ministry of Agriculture and Rural Development - MADR, 2013)

The implication of biofuel production for biodiversity is one of the important environmental concerns. Large-scale biofuel production could have both negative (Hellmann and Verburg, 2010) and positive implications for biodiversity (Ravindranath et al., 2011; Pedroli et al., 2012). The first pathway for biodiversity loss is habitat loss following land conversion for crop production, for example from forest or grassland. The second major pathway is loss of agro-biodiversity induced by intensification on croplands, under the form of crop genetic uniformity. Most biofuel feedstock plantations are based on a single species. Wild biodiversity is threatened by the loss of habitat when the area under crop production is expanded, whereas agricultural biodiversity is vulnerable in the case of largescale monocropping which is based on a narrow pool of genetic material and can also lead to reduced use of traditional varieties (FAO, 2008).

Positive implications for biodiversity of biofuel production was observed under sustainable production practices. These are involving high diversity perennials in degraded lands, which offer a range of ecosystem services along with reduced GHG emissions and with low agrochemical pollution could have positive implications for biodiversity (Ravindranath et al., 2011).

Tab. 5. Growth rate of bio-diesel primary production in the EU, 2003-2008

\begin{tabular}{|c|c|c|c|c|c|}
\hline \multirow{2}{*}{ GEO/TIME } & 2003 & 2008 & 2010 & 2012 & \multirow{2}{*}{$\begin{array}{c}\text { Growth rate (\%) } \\
2008-2012\end{array}$} \\
\hline & \multicolumn{4}{|c|}{ Thousand tons of oil equivalent (TOE) } & \\
\hline The European Union-28 & $1.182,7$ & $6.612,7$ & $8.914,5$ & $9.187,9$ & 38,94 \\
\hline The Czech Republic & 100,3 & 67,8 & 175,0 & 152,6 & 125,07 \\
\hline Denmark & 40,4 & 88,9 & 68,9 & 97,4 & 9,56 \\
\hline Germany & 594,4 & $2.236,6$ & $2.736,0$ & $2.492,0$ & 11,42 \\
\hline Spain & 92,2 & 198,2 & 754,7 & 444,6 & 124,32 \\
\hline France & 329,3 & $1.574,4$ & $1.782,7$ & $1.966,2$ & 24,89 \\
\hline Latvia & 0,0 & 25,0 & 38,6 & 80,4 & 221,60 \\
\hline Hungary & 0,0 & 122,7 & 126,6 & 128,9 & 5,05 \\
\hline The Netherlands & 0,0 & 73,3 & 337,6 & $1.040,1$ & 1318,96 \\
\hline Austria & 20,4 & 219,3 & 241,9 & 166,4 & $-24,12$ \\
\hline Poland & 0,0 & 237,5 & 348,1 & 555,2 & 133,77 \\
\hline Portugal & 0,0 & 144,5 & 279,7 & 268,8 & 86,02 \\
\hline Romania & 0,0 & 23,7 & 10,8 & 88,7 & 274,26 \\
\hline Finland & 0,0 & 95,4 & 297,1 & 257,3 & 169,71 \\
\hline Sweden & 3,7 & 129,9 & 177,4 & 318,8 & 145,42 \\
\hline The United Kingdom & 0,0 & 250,1 & 136,5 & 218,8 & $-12,51$ \\
\hline
\end{tabular}




\section{Biofuel crop production and greenhouse gas emissions}

There is a growing awarness about the need for clean energy, mainly due to concerns over climate change (Lechon et al., 2011). In the future, the agricultural sector is seen to contribute much to climate change mitigation, as growing energy demand, security of energy supply and concerns about climate change will make bioenergy crops more attractive for a future sustainable energy system (Popp et al., 2011). One way of mitigating GHG emissions is to reduce the combustion of fossil fuels. This can be achieved in a number of ways, such as by reducing enduse energy service (e.g., heat, light) demand through price increase, by reducing final energy (e.g., electricity, gasoline) without curtailing delivery of energy services through efficiency improvements (Timilsina et al., 2011a), and by substituting fossil fuels with energy produced from agricultural feed stocks (e.g., crop residues, dung, energy crops) (IPCC, 2007).

Climate-change concerns have been considered among the strongest incentives for promoting bioenergy development. Burning biomass using modern technologies or using liquid biofuels in engines may reduce emissions of regulated air pollutants relative to fossil fuel use (FAO, 2008). The control of European energy consumption and the increased use of energy from renewable sources, together with energy savings and increased energy efficiency, constitute important parts of the package of measures required to reduce greenhouse gas emissions and comply with the Kyoto Protocol to the United Nations Framework Convention on Climate Change, and with further Community and international greenhouse gas emission reduction commitments beyond 2012 (Directive 2009/28/EC).

Nevertheless, the potential climate change mitigation benefits of biofuels are already at the centre of an intense controversy in several regions of the world (Mosnier et al., 2013). For some, climate change consciousness has served as an important additional driver to the embrace of biofuels since it assists climate change mitigation efforts by displacing fossil fuel consumption (Timilsina et al., 2011b). Biofuels could contribute to the reduction of $\mathrm{CO}_{2}$ emissions from the transport sector, but it could also lead to the conversion of forest lands and pastures to crop lands, thereby increasing $\mathrm{CO}_{2}$ emissions from the agricultural sector (Mosnier et al., 2013).

The large-scale use of bioenergy is controversial because it is hypothesized to increase the competition for land and therefore raise of nitrous oxide $\left(\mathrm{N}_{2} \mathrm{O}\right)$ emissions from agricultural soils due to intensification (Popp et al., 2011). Nitrogen fertilizer applied during rapeseed cultivation could be responsible for nitrogen losses in the form of $\mathrm{N}_{2} \mathrm{O}$, which can contribute to greenhouse gas emissions. (Merino et al., 2012). Nitrous oxide is a greenhouse gas with a global warming potential around 300 times greater than that of carbon dioxide $\left(\mathrm{CO}_{2}\right)$, and it is released from nitrogen fertilizers. Moreover, greenhouse gases are emitted at other stages in the production of bioenergy crops and biofuels: in producing the fertilizers, pesticides and fuel used in farming, during chemical processing, transport and distribution, up to final use (FAO, 2008).

The Intergovernmental Panel on Climate Change (IPCC, 2006) recommended an emission factor of $1 \%$ for estimating direct $\mathrm{N}_{2} \mathrm{O}$ emission for agricultural soils (Merino et al., 2012). However, many studies have shown that the emission factor varies from 0.01 to $2 \%$ or more, and depends by soil and climate conditions, plants, type of croping, fertilizers (Lu et al., 2006; Flechard et al., 2007; Cao et al., 2008; Laville et al., 2009; Rodriguez et al., 2011; Merino et al., 2012). For example, Merino et al. (2012) reported that the emission factor from direct $\mathrm{N}_{2} \mathrm{O}$ losses from rapeseed crop was 2.54 , being significantly influenced by the environmental conditions and fertilization along the year. Most $\mathrm{N}_{2} \mathrm{O}$ emissions took place in the winter and spring period, when fertilization and the effect of warmer temperatures could have enhanced $\mathrm{N}_{2} \mathrm{O}$ losses.

In some cases, national regulations require importers to certify the sustainable cultivation of agricultural land, the protection of natural habitats and a minimum level of carbon dioxide savings for biofuels. Some countries and regional organizations (e.g. the United States of America and the EU) have suggested that net greenhouse gas balances from biofuels should range between $35 \%$ and $40 \%$ less than that of petrol. A careful analysis of these issues is important for all stakeholders, especially for exporters of bioenergy crops or fuels, as a basis for investment and production decisions and ensuring the marketability of their products (FAO, 2008).

\section{Biofuel crop production and land use}

The production of biofuels has a different dynamic in relation to fossil fuels, being based on agricultural products, where the main input is land (Rathmann et al., 2010). The demand for food, animal feed and biofuels is rising, resulting in an additional presure on land and other resources, such as water (Ravindranath et al., 2011). Less productive lands may be used for biofuel crops production, especially for second generation crops, but they need more intensive use of fertilizers and other inputs, as well as machinery. These intensified use inputs are the main factor determining the advance of the agricultural frontier into less productive areas, formerly considered marginal (Rathmann et al., 2010).

Land use change due to biofuel production can occur in two ways, (i) directly, when uncultivated land, pasture, etc. is converted to produce energy crops (e.g. grassland is used instead, in order to cultivate cereals for bioethanol), or (ii) indirectly, through displacement of food and feed crop production to new land areas previously not used for cultivation (Börjesson and Tufvesson, 2011). Many recent studies reported that the land devoted to growing biofuel crops has greatly expanded over the last decade (Li et al., 2012). Consequently, with the new agricultural and environmental policy, oilseed crops have received tax incentives and subsidies at the institutional level. Thus, the use of seeds to produce biofuels has become more profitable than for food products, once again creating impacts from changes in the land use dynamics (Rathmann et al., 2010). Therefore, better understanding of the spatio-temporal dynamics of biofuel croplands, its drivers and consequences is critical to the development of effective environmental management strategies. An important component of such work is to develop viable models that simulate biofuelsrelated land-use and land-cover changes (LULCC) (Li et al., 2012). 
331

\section{Conclusions}

Romania is one of the European Union Member States with a large potential to produce biofuels. Nevertheless, the growth of biofuel oilseeds crop production should not have adverse impact upon the environment, greenhouse gas emissions and land use. The policy to reduce dependency on fossil fuel imports has to be associated with a social and environmental policy.

A starting point might be found by establishing best practices for sustainable production of biofuels (FAO, 2008), which need to be sustained by Romanian scientific research. Good practices aim to apply available knowledge in order to address the sustainability dimensions of on-farm biofuel feedstock production, harvesting and processing. This aim applies to natural-resource management issues such as land, soil, water and biodiversity, as well as to the life-cycle analysis used to estimate greenhouse gas emissions and determine whether a specific biofuel is more climatechange friendly than a fossil fuel (FAO, 2008).

\section{Acknowledgments}

We would like to thank the National Institute of Statistics which has recently offered us online access to official statistical data. Our deepest gratitude to the Association of Universities, $\mathrm{R} \& \mathrm{D}$ Institutes and Central University Libraries in Romania which provided us with possibility to electronic access to international scientific databases and bibliography platforms through the ANELIS PLUS project. This project is granted by the Executive Agency for Higher Education, Research, Development and Innovation of Romania with the contribution of Universities and $R \& D$ Institutes.

\section{References}

Baffes J (2013). A framework for analyzing the interplay among food, fuels, and biofuels. Global Food Security 2:110-116.

Banse M, Meijl van $H$, Tabeau A, Woltjer G, Hellmann F, Verburg PH (2011). Impact of EU biofuel policies on world agricultural production and land use. Biomass and Bioenergy 35:85-2390.

Bîlteanu Gh., Fazecaş I, Salontai Al., Vasilică C, Bîrnaure V, Ciobanu Fl. (1983). Fitotehnie (Crop Production). Ed. Did Ped Bucureşti, 299 p (in Romanian).

Börjesson P, Tufvesson LM (2011). Agricultural crop-based biofuels - resource efficiency and environmental performance including direct land use changes. J Clean Prod 19:108-120.

Directive 2009/28/EC on the promotion of the use of energy from renewable sources and amending and subsequently repealing Directives 2001/77/EC and 2003/ 30/EC.2009.04.23. Off J Eur Union 2009; L 140:16-62.

EC (European Commission) (2013). Assessing the impact of biofuels production on developing countries from the point of view of Policy Coherence for Development. Contract $\mathrm{N}^{\circ}$ 2012/299193 FWC COM 2011 - Lot 1 - Studies and Technical Assistance in all Sectors. Final report, February 2013.
Erb K-H, Haberl H, Plutzar C (2012). Dependency of global primary bioenergy crop potentials in 2050 on food systems, yields, biodiversity conservation and political stability. Energy Policy 47:260-269.

EUROSTAT, 2013.

Ewing M, Msangi S (2009). Biofuels production in developing countries: assessing tradeoffs in welfare and food security. Environ Sci Policy 12:520-528.

FAO (2008). The state of food and agriculture. BIOFUELS: prospects, risks and opportunities. FAO Rome.

Flechard CR, Ambus P, Skiba U, Rees RM, Hensen A, Amstel van A et al. (2007). Effects of climate and management intensity on nitrous oxide emissions in grassland system across Europe. Agr Ecosyst Env 121:135-152.

Gamborg C, Millar K, Shortall O, Sandøe P (2012). Bioenergy and Land Use: Framing the Ethical Debate. J Agric Environ Ethics 25:909-925.

Cao G., Zhang X, Gong S, Zheng F (2008). Investigation on emission factors of particulate matter and gaseous pollutants from crop residue burning. J Environ Sci 20:50-55.

Hellmann F, Verburg PH (2010). Impact assessment on the European biofuel directive on land use and biodiversity. J Environ Manage 91: 1389-1396.

Hought L, Birch-Thomsen T, Petersen J, de Neergaard A, Oelofse $M$ (2012). Biofuels, land use change and smallholder livelihoods: A case study from Banteay Chhmar, Cambodia. Appl Geogr 34:525-532.

Hera C, Sin G, Toncea I (1989). Cultura florii-soarelui (Sunflower Crop). In: Munteanu et al. (1995). Fitotehnie (Crop Production). Ed Did Ped Bucureşti, 294 p (in Romanian).

International Energy Agency (2013). $\mathrm{CO}_{2}$ Emissions from Fuel Combustion Highlights (IEA 2013 Editon). http://www.iea.org/publications/freepublications/publicatio $\mathrm{n} /$ co2emissionsfromfuelcombustionhighlights2013.pdf.

IPCC (2007). Mitigation of Climate Changes. Agriculture (8). Intergovernmental Panel on Climate Change, Geneva.

Iriarte A, Rieradevall J, Gabarell X (2010). Life cycle assessment of sunflower and rapeseed as energy crops under Chilean conditions. J Clean Prod 18:336-345.

Iriarte A, Rieradevall J, Gabarell X (2011). Environmental impacts and energy demand of rapeseed as an energy crop in Chile under different fertilization and tillage practices. Biomass and Bioenergy 35:4305-4315.

Kampman B, Brouwer F, Schepers B (2008). Agricultural land availability and demand in 2020. Report to the Renewable Fuels Agency. Published on www.renewablefuelsagency.org, CE Delft, elft. The Netherlands.

Kuhlman T, Vasco D, Koomen E (2013). Exploring the potential of reed as a bioenergy crop in the Netherlands. Biomass and Bioenergy 55:41-52.

Laville P, Flura D, Gabrielle B, Loubet B, Fanucci O, Rolland M$\mathrm{N}$, Cellier P (2009). Characterisation of soil emissions of nitric 
oxide at field and laboratory scale using high resolution method. Atmos Environ 43:2648-2658.

Lechon Y, Cabal H, Sáez R (2011). Life cycle greenhouse gas emissions impacts of the adoption of the EU Directive on biofuels in Spain. Effect of the import of raw materials and land use changes. Biomass and Bioenergy 35:2374-2384.

Levidow L (2013). EU criteria for sustainable biofuels: Accounting for carbon, depoliticising plunder. Geoforum 44:211-223.

Li R, Guan Q, Merchant J (2012). A geospatial modeling framework for assessing biofuels-related land-use and landcover change. Agr Ecosyst Environ 161:17-26.

Lu Y, Huang Y, Zou J, Zheng X (2006). An inventory of N2O emission from agriculture in China using precipitationrectified emission factor and backgroung emission. Chemosphere 65:1915-1924.

Mediafax (2010). Investitorii străini cumpără terenuri agricole şi păduri pe bandă rulantă (Foreign investors are purchasing agricultural lands and forests) http://www.mediafax.ro/economic/ (in Romanian).

Merino P, Artetxe A, Castellón A, Menéndez S, Aizpurua A, Estavillo JM (2012). Warming potential of N2O emissions from crop in Northern Spain. Soil Till Res 123:29-34.

Mosnier A, Havlík P, Valin H, Baker J, Murray B, Feng S, Obersteiner M, McCarl BA, Rose SK, Schneider UA (2013). Alternative U.S. biofuel mandates and global GHG emissions: The role of land use change, crop management and yield growth. Energy Policy 57:602-614.

Munteanu SL, Borcean I, Axinte M, Roman Gh. V (1995). Fitotehnie (Crop Production). Ed Did Ped Bucureşti, 294 p (in Romanian).

National Institute for Statistics of Romania (2013). http://www.insse.ro/cms/en.

Negash M, Swinnen JFM (2013). Biofuels and food security: Micro-evidence from Ethiopia. Energ Policy 61:963-976.

Pakarinen A, Maijala P, Stoddard FL, Santanen A, Tuomainen P, Kymäläinen M, Viikari L (2011). Evaluation of annual bioenergy crops in the boreal zone for biogas and ethanol production. Biomass and Bioenergy 35:3071-3078.

Pedroli B, Elbersen B, Frederiksen P, Grandin U, Heikkilä R, Krogh PH, Izakovičová Z, Johansen A, Meiresonne L, Spijker J (2012). Is energy cropping in Europe compatible with biodiversity? - Opportunities and threats to biodiversity from land-based production of biomass for energy purpose. Biomass and Bioenergy 55:73-86.

Piroli G, Ciaian P, Kancs d'A (2012). Land use change impacts of biofuels: Near-VAR evidence from US. Ecol Econ 84:98-109.

Popp A, Lotze-Campmen H, Leimbach M, Knopf B, Beringer T, Bauer N, Bodirsky B (2011). On sustainability of bioenergy production: Integrating co-emissions from agricultural intensification. Biomass and Bioenergy 35:4770-4780.
Raghu S, Spencer JL, Davis AS, Wiedenmann RN (2011). Ecological considerations in the sustainable development of terestrial biofuel crops. Curr Opin Env Sust 3:15-23.

Rathmann R, Szklo A, Schaeffer S (2010). Land use competition for production of food and liquid biofuels: An analysis of the arguments in the current debate. Renew Energ 35:14-22.

Ravindranath NH, Sita Lakshmi C, Manuvie R, Balachandra P (2011). Biofuel production and implications for land use, food production and environment in India. Energ Policy 39:57375745.

Rodriguez V, Valdez-Perez MDLA, Luna-Guido M, CeballosRamirez JM, Franco-Hernández $\mathrm{O}$, Van Cleemput $\mathrm{O}$, Marsch R, Thalasso F, Dendooven L (2011). Emission of nitrous oxide and carbon dioxide and dynamics of mineral $\mathrm{N}$ in wastewater sludge, vermicompost or inorganic fertilizer amended soil at different water contents: A laboratory study. Applied Soil Ecology 49:263-267.

Rowe RR, Street NR, Taylor G (2009). Identifying potential environmental impacts of large-scale deployment of dedicated bioenergy crops in the UK. Renew Sust Energ Rev 13:271290.

Scarlat N, Dallemand JF, Gallego Pinilla F (2008). Impact on agricultural land resources of biofuels production and use in the European Union. Conference and Exhibition on Bioenergy. April 6-9, 2008. Guimarães, Portugal.

Secchi S, Kurkalova L, Gassman PW, Hart C (2011). Land use change in a biofuels hotspot: The case of Iowa, USA. Biomass and Bioenergy 35:2391-2400.

Spiertz JHJ, Ewert F (2009). Crop production and resource use to meet the growing demand for food, feed and fuel: opportunities and constraints. NJAS - Wagen J Life Sc 56(4):281-300.

Thompson W, Meyer S (2013). Second generation biofuels and food crops: Co-products or competitors? Global Food Security 2:89-96.

Timilsina GR, Csordás S, Mevel S (2011). When does a carbon tax on fossil fuels stimulate biofuels? Ecol Econ 70:2400-2415.

Timilsina GR, Shrestha A (2011). How much hope should we have for biofuels? Energy 36:2055-2069.

Ziarul financiar (2010). La ce preturi se fac ultimele tranzactii cu terenuri agricole in Romania? (What are the last transaction price of agricultural land in Romania?) http://www.zf.ro/companii/ (in Romanian, May 26, 2010).

Ziarul financiar (2012). Zece investitori au în România terenuri agricole de 300 mil. euro, o cincime din totalul deținut de străini (Ten investors own Romanian agricultural lands of 300 mil Euros, i.e. one fifth of the total owned by foreign investors). http://www.zf.ro/companii/ (in Romanian, Febr 28, 2010). 